\title{
KESEHATAN MENTAL MASYARAKAT INDONESIA (PENGETAHUAN, DAN KETERBUKAAN MASYARAKAT TERHADAP GANGGUAN KESEHATAN MENTAL)
}

\author{
Oleh: \\ Adisty Wismani Putri, Budhi Wibhawa, \& Arie Surya Gutama
}

Email:

(adistywismaniputri@gmail.com; budhiwibhawa@gmail.com; ariesurya_gutama@yahoo.com)

\begin{abstract}
ABSTRAK
Kesehatan mental merupakan sebuah kondisi dimana individu terbebas dari segala bentuk gejala-gejala gangguan mental. Individu yang sehat secara mental dapat berfungsi secara normal dalam menjalankan hidupnya khususnya saat menyesuaikan diri untuk menghadapi masalah-masalah yang akan ditemui sepanjang hidup seseorang dengan menggunakan kemampuan pengolahan stres.

Kesehatan mental merupakan hal penting yang harus diperhatikan selayaknya kesehatan fisik. Diketahui bahwa kondisi kestabilan kesehatan mental dan fisik saling mempengaruhi. Gangguan kesehatan mental bukanlah sebuah keluhan yang hanya diperoleh dari garis keturunan. Tuntutan hidup yang berdampak pada stress berlebih akan berdampak pada gangguan kesehatan mental yang lebih buruk.

Di Indonesia, berdasarkan Data Riskesdas tahun 2007, diketahui bahwa prevalensi gangguan mental emosional seperti gangguan kecemasan dan depresi sebesar 11,6\% dari populasi orang dewasa. Berarti dengan jumlah populasi orang dewasa Indonesia lebih kurang 150.000.000 ada 1.740.000 orang saat ini mengalami gangguan mental emosional (Depkes, 2007). Data yang ada mengatakan bahwa penderita gangguan kesehatan mental di Indonesia tidaklah sedikit sehingga sudah seharusnya hal tersebut menjadi sebuah perhatian dengan tersedianya penanganan atau pengobatan yang tepat.

Di berbagai pelosok Indonesia masih ditemui cara penanganan yang tidak tepat bagi para penderita gangguan kesehatan mental. Penderita dianggap sebagai makhluk aneh yang dapat mengancam keselamatan seseorang untuk itu penderita layak diasingkan oleh masyarakat. Hal ini sangat mengecawakan karena dapat mengurangi kemungkinan untuk seorang penderita pulih. Untuk itu pemberian informasi, mengedukasi masyarakat sangatlah penting terkait kesehatan mental agar stigma yang ada di masyarakat dapat dihilangkan dan penderita mendapatkan penanganan yang tepat. Kata Kunci : Kesehatan Mental, Gangguan Kesehatan Mental, Paradigma Masyarakat
\end{abstract}

\section{PENDAHULUAN}

Kesehatan mental merupakan hal yang sangat penting bagi manusia sama halnya seperti kesehatan fisik pada umumnya. Dengan sehatnya mental seseorang maka aspek kehidupan yang lain dalam dirinya akan bekerja secara lebih maksimal. Kondisi mental yang sehat tidak dapat terlepas dari kondisi kesehatan fisik yang baik.

Berbagai penelitian memberikan hasil bahwa adanya hubungan antara kesehatan fisik dan mental seseorang, dimana pada individu yang menderita sakit secara fisik menunjukkan adanya masalah psikis hingga gangguan mental. Sebaliknya, individu dengan gangguan mental juga 
menunjukkan adanya gangguan fungsi fisiknya. Sehat dan sakit merupakan kondisi biopsikososial yang menyatu dalam kehidupan manusia. Pengenalan konsep sehat dan sakit, baik secara fisik maupun psikis merupakan bagian dari pengenalan manusia terhadap kondisi dirinya dan bagaimana penyesuaiannya dengan lingkungan sekitar.

Pada konsep Person in Environment menjelaskan bahwa keberadaan individu pada sebuah lingkungan akan saling mempengaruhi. Hadirnya individu akan menghasilkan kondisi yang dinamis bagi lingkungannya, dan juga lingkungan secara langsung maupun tidak langsung akan mempengaruhi individu dan berdampak pada perubahan di diri individu tertentu. Hal ini menjelaskan bagaimana seseorang yang menderita gangguan kesehatan mental merupakan hasil dari gagalnya individu dalam beradaptasi dengan lingkungan di sekitarnya.

Kesehatan mental yang baik untuk individu merupakan kondisi dimana individu terbebas dari segala jenis gangguan jiwa, dan kondisi dimana individu dapat berfungsi secara normal dalam menjalankan hidupnya khususnya dalam menyesuaikan diri untuk menghadapi masalah-masalah yang mungkin ditemui sepanjang hidupnya. Menurut WHO, kesehatan mental merupakan kondisi dari kesejahteraan yang disadari individu, yang di dalamnya terdapat kemampuan-kemampuan untuk mengelola stres kehidupan yang wajar, untuk bekerja secara produktif dan menghasilkan, serta berperan serta di komunitasnya.

Saat ini lebih dari 450 juta penduduk dunia hidup dengan gangguan jiwa. Prevalensi gangguan mental pada populasi penduduk dunia menurut WorldHealth Organization (WHO) pada tahun 2000 memperoleh data gangguan mental sebesar 12\%, tahun 2001 meningkat menjadi 13\%. Tahun 2002 hasil survei menunjukkan bahwa 154 juta orang secara global mengalami depresi dan 25 juta orang menderita skizofrenia, 15 juta orang berada di bawah pengaruh penyalahgunaan zat terlarang, 50 juta orang menderita epilepsy dan sekitar 877.000 orang meninggal karena bunuh diri tiap tahunnya. Diprediksikan pada tahun 2015 menjadi 15\%, dan pada negara-negara berkembang prevalensinya lebih tinggi.

Dilihat dari angka penderita gangguan mental yang tiap tahun meningkat maka seharusnya perawatan atau pengobatan yang ditawarkan juga semakin beragam, namun sayangnya hal ini tidak berlaku di Indonesia dimana penderita gangguan kesehatan mental masih dianggap sebagai sesuatu yang aneh dan penderitanya harus dikucilkan. Berbagai stigma diberikan pada penderita gangguan kesehatan mental sehingga untuk keluarga penderitapun lebih memilih menutupi kondisi anggota keluarganya.

Hal ini sangat disayangkan mengingat di zaman sekarang ini masyarakat diberikan berbagai opsi untuk pengobatan penderita gangguan kesehatan mental namun lebih memilih untuk berobat ke dukun atau orang pintar karena masih beranggapan bahwa sakit mental atau sakit jiwa itu dikarenakan adanya gangguan makhluk halus atau sebagainya. Oleh karena itu, sudah seharusnya masyarakat diedukasi tentang kesehatan mental, dan bagaimana cara penanganannya, agar penderita dapat diminimalisir kondisi buruk mentalnya dan masyarakat akan menghilangkan pandangan-pandangan yang tidak sesuai terhadap para penderita gangguan kesehatan mental

\section{PEMBAHASAN}

Gangguan kesehatan mental merupakan kondisi dimana seorang individu mengalami kesulitan dalam menyesuaikan dirinya dengan kondisi di sekitarnya. Ketidakmampuan dalam memecahkan sebuah masalah sehingga menimbulkan stres yang berlebih menjadikan kesehatan mental individu tersebut menjadi lebih rentan dan akhirnya dinyatakan terkena sebuah gangguan kesehatan mental.

Di Indonesia, berdasarkan Data Riskesdas tahun 2007, diketahui bahwa prevalensi gangguan mental emosional seperti gangguan kecemasan dan depresi sebesar 11,6\% dari populasi orang dewasa. Berarti dengan jumlah populasi orang dewasa Indonesia lebih kurang 150.000.000 ada 1.740.000 orang saat ini mengalami gangguan mental emosional (Depkes, 2007). 
Menurut data Riskesdas 2007 angka rata-rata nasional gangguan mental emosional (cemas dan depresi) pada penduduk usia 15 tahun adalah 11,6\% atau sekitar 19 juta penduduk. Sedang gangguan jiwa berat rata-rata sebesar $0,46 \%$ atau sekitar 1 juta penduduk. Dari angka yang besar tersebut, penderita gangguan mental yang diberikan fasilitas pengobatan sangatlah sedikit. Menurut perhitungan utilisasi layanan kesehatan jiwa di tingkat primer, sekunder dan tersier kesenjangan pengobatan diperkirakan $>90 \%$ (Diatri, 2011). Hal ini berarti bahwa hanya $<10 \%$ orang dan masalah kesehatan jiwa terlayani di fasilitas kesehatan. Kerugian ekonomi minimal akibat masalah kesehatan jiwa berdasarkan hasil Riskesdas 2007 tersebut mencapai Rp.20T, merupakan jumlah yang sangat besar jika dibandingkan dengan masalah kesehatan lainnya (Depkes, 2007).

Gangguan kesehatan mental dapat diperoleh semenjak anak dari dalam kandungan maupun ketika seseorang tumbuh dewasa namun dalam perkembangannya ditemui hal-hal yang dapat berdampak pada stres yang berlebihan. Kehidupan yang semakin modern membawa berbagai macam tuntutan yang harus dipenuhi. Bukan hanya karena sifatnya yang wajib atau penting melainkan keinginan diakui oleh masyarakat menjadikan individu merasa harus mengikuti trend yang sedang berlangsung tanpa sadar akan kapasitasnya.

\section{Penyebab Gangguan Kesehatan Mental}

Menurut Undang-undang No 3 Tahun 1966 yang dimaksud dengan "Kesehatan Jiwa" adalah keadaan jiwa yang sehat menurut ilmu kedokteran sebagai unsur kesehatan, yang dalam penjelasannya disebutkan sebagai berikut:

"Kesehatan Jiwa adalah suatu kondisi yang memungkinkan perkembangan fisik, intelektual dan emosional yang optimal dari seseorang dan perkembangan itu berjalan selaras dengan keadaan orang lain".

Makna kesehatan jiwa mempunyai sifat-sifat yang harmonis (serasi) dan memperhatikan semua segi-segi dalam kehidupan manusia dan dalam hubungannya dengan manusia lain. Jadi dapat disimpulkan bahwa kesehatan jiwa adalah bagian integral dari kesehatan dan merupakan kondisi yang memungkinkan perkembangan fisik, mental dan sosial individu secara optimal, dan yang selaras dengan perkembangan orang lain. Seseorang yang "sehat jiwa atau mental" mempunyai ciri-ciri sebagai berikut:

1. Merasa senang terhadap dirinya serta

a. Mampu menghadapi situasi

b. Mampu mengatasi kekecewaan dalam hidup

c. Puas dengan kehidupannya sehari-hari

d. Mempunyai harga diri yang wajar

e. Menilai dirinya secara realistis, tidak berlebihan dan tidak pula merendahkan

2. Merasa nyaman berhubungan dengan orang lain serta
a. Mampu mencintai orang lain
b. Mempunyai hubungan pribadi yang tetap
c. Dapat menghargai pendapat orang lain yang berbeda
d. Merasa bagian dari suatu kelompok
e. Tidak "mengakali" orang lain dan juga tidak membiarkan orang lain "mengakali" dirinya

3. Mampu memenuhi tuntutan hidup serta

a. Menetapkan tujuan hidup yang realistis

b. Mampu mengambil keputusan

c. Mampu menerima tanggungjawab

d. Mampu merancang masa depan

e. Dapat menerima ide dan pengalaman baru 


\section{f. Puas dengan pekerjaannya}

Gangguan kesehatan mental adalah kondisi individu yang memiliki gejala-gejala gangguan kejiwaan. Terdapat berbagai unsur penyebab terjadinya gangguan kesehatan mental pada seseorang, gangguan kesehatan mental ini dibagi menjadi tiga kategori penyebab yakni faktor-faktor somatogenik, psikogenil, dan sosiogenik.

Faktor somatogenik yang terdiri dari neroanatomi, nerofisiologi, nerokimia, tingkat kematangan dan perkembangan organik, dan faktor-faktor pre dan perinatal. Faktor psikogenik meliputi interaksi ibu-anak yang tidak abnormal seperti tidak adanya rasa percaya, peranan ayah, sibling rivaly, intelegensi, hubungan dalam keluarga, pekerjaan, permainan dan masyarakat, kehilangan yang menyebabkan kecemasan, depresi, rasa malu atau salah, pola adaptasi dan pembelaan sebagai reaksi terhadap bahaya, dan tingkat perkembangan emosi. Faktor sosiogenik yang di dalamnya terdapat kestabilan keluarga, pola mengasuh anak, keluarga dengan ekspresi emosi tinggi atau rendah, tingkat pendapatan atau ekonomi, tempat tinggal, masalah kelompok minoritas yang berprasangka, fasilitas kesehatan, pendidikan, serta kesejahteraan yang tidak memedai, pengaruh rasial dan keagamaan, dan nilai-nilai yang dijadikan pedoman. (http://elib.fk.uwks.ac.id/)

Dari ketiga faktor tersebut diketahui bahwa penyebab gangguan kejiwaan atau gangguan mental tidak hanya dapat disebabkan salah satu faktor, karena sifat manusia yang utuh dimana sistem dalam diri manusia merupakan sebuah kesatuan oleh karena itu sangat memungkin bahwa penyebab gangguan kesehatan mental merupakan kombinasi dari ketiga kategori dengan satu kategori sebagai penyebab utamanya. Oleh sebab perihal ini lah dalam melakukan assessment pada penderita haruslah dilakukan secara detail dan menyeluruh.

Menurut Santrock (1999) penyebab gangguan jiwa pada umumnya dikategorikan menjadi aspek jasmaniah atau biologi seperti contohnya keturunan, kegemukan yang cenderung psikosa manik depresi dan dapat pula menjadi skizofernia, tempramen karena orang yang telalu sensitif, penyakit, dan cedera tubuh.

Santrock juga menjelaskan bahwa gangguan jiwa juga dapat disebabkan oleh faktor psikologi dimana seseorang dengan pengalaman frustasi, kegagalan dan keberhasilan yang dialami akan mewarnai perilaku, kebiasaan, dan sifatnya di masa yang akan datang. Pernyataan bahwa hidup manusia dapat dibagi atas 7 masa dan pada suatu keadaan tertentu dapat mendukung terjadinya gangguan jiwa.

\section{Gangguan Kesehatan Mental di Indonesia}

Sebagai sebuah negara yang semakin berkembang, Indonesia tidak hanya mengikuti perkembangan trend yang sifatnya positif namun juga membawa perkembangan yang sifatnya merugikan seperti gangguan jiwa. Dijelaskan sebelumnya bahwa gangguan mental atau jiwa dapat disebabkan oleh aspek dari luar individu, seperti halnya kehidupan dalam bermasyarakat. Ketika seseorang dituntut untuk memenuhi atau melakukan hal-hal di luar kapasitasnya maka akan menimbulkan stres yang berlebihan, dan jika tidak ditangani dengan tepat maka kondisinya akan menjadi lebih buruk dan berakhir pada gangguan kejiwaan.

Diketahui dari Guru Besar ilmu Kesehatan Masyarakat Universitas Indonesia, Ascobat Gani kerugian ekonomi minimal akibat masalah kesehatan mental berdasarkan Riskesdas 2007 adalah sebesar Rp 20 triliun. Jumlah pasien Jamkesmas rawat inap terbanyak di rumah sakit (RS) Kelas A pada 2010 lalu adalah Hebephrenic Schizophrenia (1.924 orang), Paranoid Schizophrenia (1.612 orang), Undifferentiated Schizophrenia (443 orang), Schizophrenia Unspecified (400 orang) dan Other Schizophrenia (399 orang). Jumlah itu belum termasuk pasien rawat jalan. Dari total populasi risiko 1,093,150 hanya 3.5 persen atau 38,260 yang baru terlayani di rumah sakit jiwa, rumah sakit umum, atau pusat kesehatan masyarakat dengan fasilitas memadai. Menurut Pendiri Rumah 
Komunitas Penderita Skizofrenia Indonesia (KPSI) Bagus Utomo, penanganan atau proses pemulihan pasien dengan gangguan jiwa di Indonesia masih buruk. (www.merdeka.com)

Di negara-negara maju sudah banyak cara pecegahan dan juga pengobatannya, berbeda dengan di Indonesia khususnya beberapa daerah yang dalam urusan kesehatan mental masih jauh dari memadai, dan cenderung bersifat primitif. Minimnya informasi mengenai gangguan kesehatan mental membuat masyarakat masih menganggap bahwa masalah ini tidak dapat diselesaikan, sehingga tidak ada pengobatan yang dapat diberikan pada penderita gangguan kesehatan mental kecuali diasingkan atau dikucilkan yang terkadang caranya tidak manusiawi seperti mengurung di dalam sebuah kandang atau dipasung.

Menurut Pendiri Rumah Komunitas Penderita Skizofrenia Indonesia (KPSI) Bagus Utomo, penanganan atau proses pemulihan pasien dengan gangguan jiwa, salah satunya Skizofrenia di Indonesia masih buruk. Masih terdapat 18 ribu penderita gangguan kesehatan mental khususnya orang dengan Schizophrenia (ODS) yang dipasung. Umumnya dipasung dengan rantai. Banyak tempat-tempat pengobatan jiwa di Indonesia ini tidak manusiawi. Ada pasien yang disuntik asalasalan atau di pasung sampai mengidap penyakit kulit.Ada yang tidak manusiawi, dipaksa mengemis, pasiennya sampai korengan, kudisan, kurus, tak diberi baju. Belum lagi biaya perawatan di beberapa rumah sakit dan yayasan itu mahal. (www.merdeka.com)

Data yang telah dijabarkan sebelumnya sedikit menggambarkan bagaimana kondisi para penderita gangguan kesehatan mental. Dukungan masyarakat yang menjadi aspek penting dalam berkembangnya seseorang menjadi hal yang sangat sulit diraih oleh penderita gangguan kesehatan mental. Masyarakat sulit menerima kondisi para penderita, mereka menganggap para penderita adalah orang berbahaya, pasien yang tidak dapat pulih kesehatan mentalnya, dan layak untuk diasingkan.

Memberikan edukasi mengenai kesehatan mental, gangguan kesehatan mental, berikut dengan penanganannya bukan hanya dibutuhkan oleh keluarga yang memiliki anggota keluarga yang menderita gangguan kesehatan mental, melainkan kepada masyarakat pada umumnya. Dalam konsep person in environment yang menjadi salah satu ciri khas dari pekerjaan sosial menjelaskan bahwa keberadaan seseorang individu akan mempengaruhi dann dipengaruhi oleh lingkungan di sekitarnya. Untuk perihal kesembuhan penderita gangguan kesehatan mental maka seluruh lapisan masyarakat wajib dan berhak mendapatkan informasi yang selengkap-lengkapnya untuk menciptakan lingkungan (sosial) yang proporsional bagi kesembuhan para penderita.

Dengan memberikan pengetahuan mengenai kesehatan mental atau kejiwaan (termasuk psikososial) kepada masyarakat maka secara bertahap stigma 'orang aneh yang harus dikucilkan' akan sedikit demi sedikit berkurang, dan bagi keluarga yang anggotanya memiliki gangguan kesehatan mental atau kejiwaan akan langsung memberikan pengobatan di tempat yang sesuai, selain itu dengan terbukanya pikiran masyarakat maka secara berkala profesi pekerja sosial dalam bidang medis khususnya akan ikut terangkat. Tersedianya berbagai macam treatment seharusnya dapat menjadi solusi atau jawaban bagi masyarakat yang mempertanyakan dan meragukan akan kesembuhan bagi para penderita gangguan kesehatan mental atau kejiwaan.

Kuatnya stigma negatif masyarakat pada penderita gangguan kesehatan mental menjadikan penderita tidak mendapatkan perawatan yang sesuai. Dianggap sebagai sebuah aib, keluarga penderita gangguan kesehatan mental lebih memilih mengurung anggota keluarga yang terkena gangguan mental di rumah, bahkan masih sering ditemui yang memilih memasung karena berpikiran bahwa penderita gangguan kesehatan mental dapat membahayakan keselamatan orang lain.

Dengan stigma negatif tersebut maka akan sulit institusi kesehatan yang menangani pesoalan ini untuk membantu mereka yang membutuhkan perawatan. Minimnya pengetahuan tentang kesehatan mental,maupun gangguan kesehatanmental menjadikan masyarakat memilih untuk diam, dan melakukan hal yang sangat sederhana sebagai bentuk pengobatan. Kurangnya keterbukaan masyarakat terhadapa gangguan kesehatan mental menjadikan masyarakat terjebak di perspektif masing-masing. 
Untuk mencapai jiwa yang sehat diperlukan usaha dan waktu untuk mengembangkan dan membinanya. Jiwa yang sehat dikembangkan sejak masa bayi hingga dewasa, dalam berbagai tahapan perkembangan. Pengaruh lingkungan terutama keluarga sangat penting dalam membina jiwa yang sehat.

Apabila seseorang mengalami perubahan maka akan terjadi reaksi, baik secara jasmani maupun kejiwaan yang disebut dengan stres. Sebagai contoh misalnya para karyawan atau manajer merasakan stres apabila ada pekerjaan yang menumpuk atau jika ada kesulitan dalam hubungan kerja. Stres dapat terjadi pada setiap orang dan pada setiap waktu, karena stres merupakan bagian dari kehidupan manusia yang tidak dapat dihindarkan. Pada umumnya orang menyadari adanya stres, namun ada juga yang tidak menyadari hahwa dirinya mengalami stres.

Reaksi seseorang terhadap stres dapat bersifat positif maupun dapat bersifat negatif. Reaksi yang bersifat negatif atau merugikan, jika terjadi keluhan atau gangguan pada orang tersebut. Reaksi bersifat positif, jika menimbulkan dampak yang menjadi pendorong agar orang berusaha. Stres yang bersifat negatif/merugikan dapat terjadi apabila stres terlalu berat atau berlangsung cukup lama.

\section{PENUTUP}

Kesehatan mental atau kejiwaan merupakan hal vital bagi manusia sama halnya seperti kesehatan fisik atau tubuh pada umumnya. Dengan sehatnya mental atau kejiwaan seseorang maka aspek kehidupan yang lain dalam dirinya akan bekerja secara lebih maksimal.

Indonesia sebagai negara yang terus berkembang dalam berbagai aspek menjadikan masyarakatnya semakin modern, yang identik dengan meningkatkatnya tuntutan kebutuhan hidup yang harus dipenuhi sehingga berdampak pada tekanan yang berlebihan di pikiran masyarakat, sehingga menjadi rentan terkena stress yang secara tidak langsung (sedikit-banyak) dapat menimbulkan gangguan kesehatan mental atau kejiwaan. Penderita gangguan kesehatan mental masih dianggap sebagai hal yang memalukan atau sebuah aib bagi keluarga atau kerabat yang salah satu anggota keluarga mengalami gangguan kesehatan mental atau kejiwaan. Masyarakat Indonesia beranggapan bahwa gangguan kesehatan mental atau kejiwaan tidak dapat disembuhkan sehingga bagi penderitanya layak dikucilkan.

Kuatnya stigma negatif masyarakat pada penderita gangguan kesehatan mental menjadikan penderita tidak mendapatkan perawatan yang sesuai. Dianggap sebagai sebuah aib, keluarga penderita gangguan kesehatan mental lebih memilih mengurung anggota keluarga yang terkena gangguan mental di rumah, bahkan masih sering ditemui yang memilih memasung karena berpikiran bahwa penderita gangguan kesehatan mental dapat membahayakan keselamatan orang lain.

Dengan stigma negatif tersebut maka akan sulit institusi kesehatan yang menangani pesoalan ini untuk membantu mereka yang membutuhkan perawatan. Minimnya pengetahuan tentang kesehatan mental,maupun gangguan kesehatanmental menjadikan masyarakat memilih untuk diam, dan melakukan hal yang sangat sederhana sebagai bentuk pengobatan. Kurangnya keterbukaan masyarakat terhadapa gangguan kesehatan mental menjadikan masyarakat terjebak di perspektif masing-masing.

\section{DAFTAR PUSTAKA}

Arifin, Mokhamad. (2012). "Rancangan Instrumen Deteksi Dini Gangguan Jiwa Untuk Kader dan Masyarakat di Kabupaten Pekalongan”. Jurnal Ilmiah Kesehatan Vol V No.2 September 2006.

Dewi, Kartika Sari. 2012. Buku Ajar Kesehatan Mental. UPT UNDIP Press : Semarang.

Kaplan, Tony. 2009. Children and Adolescent with Mental Health Problems. The Royal College of Psychiatrists : London.

Semrud-Clikeman, Margaret. 2007. Social Competence in Children. Springer Science+Business Media, LCC: USA.

Wibhawa,Budhi,dkk. 2010. Dasar-dasar Pekerjaan Sosial. Bandung. Widya Padjadjaran 
Modul Kesehatan Mental Dalam Kedaruratan. WHO

Faperta.ugm.ac.id. Kesehatan Jiwa. Diunduh pada tanggal 17 November 2014. Pukul 21.05 WIB. Faperta.ugm.ac.id. Kesehatan Jiwa. Diunduh pada tanggal 20 november 2014. Pukul 21.05 WIB. http://www.merdeka.com. Di Indonesia, ada 18 ribu penderita gangguan jiwa berat dipasung. Diakses pada tanggal 14 Desember 2014. Pukul 20.05 WIB. 